\title{
The Impact of Local Transport Systems on Green Infrastructure - Policy Versus Reality. The Case of Poznan, Poland
}

\author{
Jędrzej Gadziński
}

Jędrzej Gadziński, Adam Mickiewicz University in Poznan, Institute of Socio-Economic Geography and Spatial Management, Poland (jedgad@amu.edu.pl)

\begin{abstract}
The main objective of the study was (1) to assess the level of negative impact of the road transport sector on the green infrastructure; (2) to compare the policy on green infrastructure with the actual direction of changes in transport systems; (3) to assess plans for transport development and some predictions on future impact. The research was carried out in the Poznan Metropolitan Area with the use of kernel density estimation (GIS). The analyses show that the key problem is the fragmentation of valuable natural areas and the routing of high traffic intensity roads through and nearby these areas which cause conflicts. The most negative transportation influence occurs in the agglomeration centre, where the quality of the environment is already low. At the same time existing land-use and transport strategies propose solutions neutralizing these negative impacts. Nevertheless current trends and especially new transport investment seem to negate official strategies and intensify the negative impacts on the green infrastructure.
\end{abstract}

Keywords: green infrastructure, transport systems, roads impact, road ecology, GIS, Poznan

\section{Introduction}

Urban centres of growth seem to be areas where the construction of a green infrastructure network is extremely difficult. This is due especially to large concentrations of inhabitants, intensive land-use and the high density of different infrastructural elements. This raises two questions for the authorities in many big cities: 1) What are the most significant threats to green infrastructure in urban areas? 2) How can green corridors be organised in these areas, while safeguarding all the basic needs of local communities? One of the most important problems seems to be the relationship between green infrastructure and local transport systems.

In past decades, complicated transport systems were developed in urban areas to ensure efficient transportation for residents. This process was especially intensive in suburban areas (Gayda and Lautso, 2007; Banister, 2011). Because of intensive urbanisation, these systems are being continually modified (by infrastructural investment, organisational changes in public transport, new legal regulations) and have a strong impact on traffic conditions in urban areas as well as on the local environment. This is particularly the case in post-Soviet countries, which joined the European Union in the twentieth century (Gadziński, 2013). EUfinanced investment between 2004 and 2014 significantly contributed to the reorganisation of local transport systems (Gadziński, 2014). In effect, new conflicts of interests have developed and the pressure on the green infrastructure is still growing. In these conditions, local authorities have to face the challenge of ensuring sustainable growth of the whole urban area. Their primary task is to serve residents needs but it is also very important to maintain the good quality of the local environment (Button and Nijkamp, 1997). It appears to be reflected in transport policies that strongly emphasize the problem of negative impacts on the green infrastructure. But is it actually reflected in real activities and investment in the transport infrastructure? 
The main objective of the study was to assess the negative impact of the transport sector (with the focus on road transport) on the green infrastructure and to show currently proposed solutions. Secondly, I would like to compare policy on green infrastructure with the actual direction of changes in transport systems. Finally, I present an assessment of plans for transport development and some predictions on future impacts. The research was carried out in the Poznan Metropolitan Area (PMA), where there are many valuable natural areas, which are essential elements of the local green infrastructure. The PMA can be seen as a good example of an urban area undergoing intensive urbanisation where the pressure of motorisation on the natural environment will continue to grow. At the same time, the recent trends in local strategies towards reducing car traffic flows and negative impacts on the environment have become important issues for the development of a local transport system. However, recent years have shown that the outcomes of this policy have proved rather unsatisfactory. It could therefore be postulated that a reduction of transport impacts on the natural environment in the PMA is rather a fiction.

There are four main parts to the present study. A review of the literature and a brief presentation of the PMA are followed by an analytical chapter. The negative impact of transport is calculated using kernel density analysis (GIS program). Then the most important assumptions of local policies on this subject are identified. They are discussed in the light of plans for road infrastructure development. Finally, the predicted negative effects are evaluated, followed by overall conclusions.

\section{Urban transport and green infrastructure}

\section{Road effects}

Although the term and concept of "green infrastructure" is relatively new, relations between transport systems and green areas have been attracted attention for ages. As Coffin (2007) noticed, interest in this subject has significantly increased since the 1970s and there are now many publications addressing the ecological effects of roads and traffic. This increase in research is reflected in the emergence of the new science of 'road ecology'. This term was established and popularised by Forman (1998) to define the wide range of effects roads have on the natural environment. The same author (with others, Forman et al. 2003) soon published a complex, interdisciplinary book on the subject. This literature and the growing interest of scientists in the ecological effects of roads have led to the establishment of a new discipline rooted in ecology, geography, engineering and planning.

Current research on the impact of roads on the environment focus on different aspects and types of effect (Spellerberg, 1998). For example, there are a significant number of studies on biota and habitats. Investigations of the effects of roads on wildlife populations (Forman and Alexander, 1998; Harris and Scheck, 1991) or population fragmentation (Nellemann et al., 2001, Develey and Stouffer, 2001, Smith et al., 2005) seem to be the most common. But other aspects such as impacts on plant populations or changes in the abiotic components of ecosystems have also been addressed. The deterioration in the quality of the atmosphere and hydrosphere (Rogge et al., 1993; Polkowska et al., 2001) and irreversible changes in landscape (Saunders et al., 2002; Hawbaker et al., 2006) are important topics in this field. Most authors agree that roads generate different types of negative effect from the outset of construction. What is more, these effects increase over time in most cases. According to Spellerberg (1998), three different types of ecological road effects are to be distinguished: (1) effects during construction, (2) short term effects, and (3) long term effects. In the first category he lists such phenomena as loss of habitat and biota or changes in hydrology during construction works. Short term effects include such phenomena as the creation of new road edge microclimates and new habitats for edge species; growing plant and animal mortality; 
and animal migration. Finally, among the long term effects Spellberg (1998) identifies habitat damage and loss; the isolation of populations; the facilitation of pest species dispersal; and changes in species composition. A complex review of different types of effects and impact of roads is to be found in Forman et al. (2003).

Recent studies examine not only effects on the environment but also types of impact. An important section of the literature discusses pollution and disturbance effects on biota and ecosystems (Schonewald-Cox and Buechner, 1992; Hellawell 1988; Holden and Høyer, 2005). As Spellerberg (1998) points out, the range and scale of emissions of noise, gases, dusts, artificial light, and heavy metals are examples of road impacts also taken into account in recent investigations. A frequent topic is measurement of the negative impact of transport networks (Li et al., 1999; Geneletti, 2003; Glasson et al., 2013; Pant and Harrison, 2013; Macias and Gadzinski, 2013). These analyses make a major contribution to studies on environmental impact assessment (EIA; see Glasson, 2013). They are concerned with different types of impact such as emissions, noise, global warming, or present and future effects on the natural environment (for example changes in land use, landscape, the fragmentation of green areas). Different methods of such investigations should also be mentioned, such as laboratory analysis, statistical and econometric models, and even sociological surveys (see João, 2002).

Finally, I should also mention the group of studies and reports on reducing the negative impact of transport infrastructure on the local environment (Bennett, 1991; Angold, 1997; Kenworthy, 2006). They focus on such ideas as reducing road mortality, limiting the barrier effects of roads and railways, and creating buffer zones and filters to protect valuable natural areas. Different tools including new technological and engineering solutions as well as methods of land conservation are considered as methods of reducing negative road impact. It should be stressed that most authors focus on highways and urban road networks, because of they come highest on the scale of negative impact. Cities appear to be particularly affected by this problem (Newman, 2006). Because of the concentration of people in a relatively small area, transport networks in cities are usually very extensive and traffic flows much higher than in rural areas. It should also be noted that cities are complex structures, which are constantly changing; changes in transport systems cannot be understood without analysis of the urbanisation process. New demographic trends, the reorganisation of urban space, changes in land use may cause significant functional transformations in transport conditions in cities. In recent years, urban sprawl has caused substantial changes in transport systems in metropolitan areas (Johnson 2001). Lower settlement density has reduced the effectiveness of public transport. In effect, cars are more popular in the suburbs (Newman and Kenworthy, 1999; Chapman, 2007). This has a very significant and negative impact on green areas in cities as well as on the health and living conditions of the population. New methods for neutralising negative impacts are therefore constantly being developed.

Among the many initiatives to conserve land in urban areas, the concept of green infrastructure is to the fore. Benedict and McMahon (2006, p. 5) define it as "the ecological framework needed for environmental, social and economic sustainability," a conservation approach focused on "actions in concert with land development, growth management and built infrastructure planning" (p. 6). According to Wickham et al. (2010), green infrastructure can be seen as a system of "hubs" (large areas of natural vegetation such as protected areas, national and private forests, biologically active open spaces, parks) and "links" (linear features such as smaller protected areas, river and stream corridors, linear woody buffers). The main objective of this concept is to provide "a solution for continued land fragmentation and the resulting degradation of natural system" (McDonald et al., 2005, p. 13). From this point of view, the neutralisation of negative road impacts is crucially important in establishing complex networks of green infrastructure in urban areas. 


\section{EU Transport policy and the environment}

Since the 1990s, environmental issues have played a foremost role in EU. This is due to the increasing salience of sustainable development, the fight against global warming, action to reduce $\mathrm{CO}_{2}$ emissions and improve the quality of life (especially in highly urbanised areas). Environmental issues are also prominent in transport strategy. EU transport policy - the White Paper on Transport European transport policy for 2010: time to decide adopted in 2001 included a list of measures to improve the sustainability of transport systems. It was a short-term strategy for developing the transportation sector throughout the union. Many sections of this document point to problems that relate directly to major urban centres and connecting corridors. The key urban transport issues included increasing congestion, pollution and noise levels, as well as the excessive development of costly road infrastructure and its large land consumption (see Banister 2011). In the case of freight transport, negative factors include the high percentage of vehicles involved and "bottlenecks" in road traffic. Among the solutions proposed are the improvement of urban transport quality, the development of new environment-friendly technologies, additional investment in railway transport, the promotion of inland waterway transport and the creation of trans-European corridors under the TEN-T programme (in particular, the inclusion of the main centres in new member states in the European transport network after 2004).

In 2011, the European Commission adopted a new strategy for a much longer time perspective. The new White Paper on Transport entitled Roadmap to a Single European Transport Area - Towards a competitive and resource efficient transport system (2011) provides a specific roadmap for the development of the transport sector with a shorter outlook by 2030 and longer by 2050. In addition to the provisions that focus on different transportation sectors, the document also includes a vision for creating a competitive and sustainable urban transport system ("Clean urban transport and commuting to work") with four basic postulates:

- transition to greener transport in cities (elimination of conventionally-fuelled cars, efficient and accessible public transport, good travel conditions by bicycle and on foot, fewer accidents, low transport emissions),

- use of public transport on a wider scale (high availability and frequency) and the use of space conducive to reducing the need for mobility,

- widespread use of smaller, lighter and more specialized passenger vehicles,

- limited transport of goods in cities (through appropriate combination of transporting goods over long distances and transport over the last kilometres, reducing individual supplies, the development of intelligent transportation systems).

The document clearly indicates that the future development of transport systems in cities will mainly concern public transport. Private motor transport was considered the least efficient and most emissive (compare Whitelegg 1994, Mess 2010). This direction is supported by the objectives of the strategy: by 2030 to reduce the number of conventionally fuelled cars by half, and by 2050 to eliminate them completely. At the same time, the 'polluter pays' and 'user pays' principles are to be pursued, introducing charges to be collected from road users (taking into account construction and infrastructure maintenance costs as well as external expenses, including environmental costs). This would finance the construction and maintenance of a modern transportation infrastructure and the neutralisation of negative impacts on the environment.

The 2011 transport policy provides for the continuous development of the TEN-T corridor network connecting the largest European centres. Greater emphasis has been put on investment in rail transport (including the high-speed rail network), as well as inland waterway transport. Intermodal solutions are particularly stressed, including the connection of airports, sea ports and river ports with the railway network. What is more, the document 
assumes that transporting goods over long distances by truck will be much decreased. By 2030, the weight of goods transported in this manner (over a distance greater than $300 \mathrm{~km}$ ) is to be reduced by $30 \%$, and by 2050 - by $50 \%$.

The solutions proposed in EU transport strategies show the increasing importance of environmental issues in urban transport policy. In the Polish context, too, similar ideas have been adopted in urban transport strategy. Recent proposals include reducing traffic intensity through the better use and availability of public transport, the introduction of parking fees and limited parking zones, increased traffic fluidity, restrictions on residential development near roads with high traffic intensity. But most documents on the national and local levels are much less restrictive and most make suggestions without concrete regulations.

\section{Poznań as a case study}

At the beginning of the twenty-first century, the Poznan Metropolitan Area (PMA; the city of Poznan and surrounding Poznan poviat) is one of the most important centres of growth in the Polish urban system. It covers more than $2100 \mathrm{~km}^{2}$ and with a population of almost 900,000. Poznan ranks fifth in Poland in terms of population (548,000 in 2013) and has a diversified economy with a well-developed industrial base and a wide range of services. What is more, Poznan hosts a major international trade fair and has a strong position in the field of academic education. Poviat poznanski surrounds Poznań and consists of 17 communes (fig. 1). It has a population of 352,000 and the largest cities are Swarzedz $(31,000)$ and Lubon $(31,000)$. But most of the area (in terms of Polish administrative classification) is treated as rural.

In recent decades, the PMA has experienced very intensive urbanisation. The structural changes this has brought have been depopulation of the city centre and population growth in surrounding areas. Since 2001 Poznan has lost $5.41 \%$ of its population. Over the same period, the number of inhabitants in Poznan poviat communes has increased by $33.05 \%$. One of the main reasons has been the rapid development of new road links. Especially since 2004, after Poland's accession to the European Union and adoption of common transport policy rules, transport networks at the national, regional, and local levels have begun to change at a much faster pace. This was particularly evident in the country's major cities such as Poznań, which have invested significant resources in the infrastructure of various means of transport. The lion's share was spent on road network development.

Suburbanization has caused significant changes in transport behaviour. Rising transport needs (such as increasing travel distances) and growing motorisation have caused congestion problems. Between 2002 and 2013, the number of cars in the PMA increased by 55.33\%. Car traffic volumes on all categories of road also rose significantly. Other changes in road networks and traffic in the PMA are shown in table 1. Almost all confirm the rapid transformation of the local transport network.

Table 1: Selected characteristics of the road network and traffic in the PMA

\begin{tabular}{lll}
\hline Road and traffic characteristics & Situation in the 2000s & Situation in the 2010s
\end{tabular}

\begin{tabular}{llll}
\hline $\begin{array}{l}\text { Motorisation level in the PMA } \\
\text { (number of cars per } \begin{array}{l}365.6 \\
(000\end{array}\end{array}$ & $\begin{array}{l}567.9 \\
(2002)\end{array}$ \\
inhabitants)* & & \\
Car traffic volumes on national roads & 505,365 & 572,459 \\
in Poznan poviat** & $(2005)$ & $(2010)$ \\
Car traffic volumes on regional roads & 182,191 & 239,540 \\
in Poznan poviat** & $(2005)$ & $(2010)$ \\
Length of roads in Poznan (in km)*** & 1120 & 1039 \\
\hline
\end{tabular}




\section{Modal split in Poznan***}

Modal split in Poviat poznan***
(2004)

public transport - $37 \%$

cars $-53 \%$

bicycles $-2 \%$

walking $-8 \%$

(2000)

public transport $-25 \%$

cars $-51 \%$

bicycles, walking and others $-24 \%$

(2000)
(2013)

public transport - $43 \%$

cars $-40 \%$

bicycles $-4 \%$

walking $-13 \%$

(2013)

public transport $-18 \%$

cars $-66 \%$

bicycles $-5 \%$

walking $-11 \%$

(2013)

Source: * Central Staristical Office; ** General Directorate of National Roads and Motorways (GDDKiA); *** Urban Road Management in Poznań (ZDM) (the years of particular data sources are given in brackets in the table).

Because of rapid transport network development in the PMA, the pressure on the natural environment has been growing. In last decades, according to Gaj (2008), road transport has become one of the most emissive sectors (together with the energy industry) in Poznan, causing significant deterioration of air quality. He also estimates an increase in emissions of different gases from the transport sector in the city, and, for example, a rise in the level of nitrogen oxides between years 1990 and 2005 of more than $950 \%$. There are also problems with noise emissions. According to data from the Institute of Acoustics in Poznan, almost all major roads generate noise exceeding the legal limits by 10-20 decibels.

New transport investment, increasing car traffic, and rising emissions could have also a significant impact on green areas in the PMA and, in effect, lower its security level $(\mathrm{Yu}$, 1996). Interestingly, despite suburbanisation problems, the network of green infrastructure in the area under study is rather extensive. Many larger forest complexes or rivers valleys are protected as national or landscape parks and Natura 2000 areas. Moreover, four green corridors in Poznan were established (mainly in river valleys) in the first part of the twentieth century and still exist despite growing pressure from developers (they are protected by municipal urban planning policy). In total, green infrastructure (including water bodies) covers $821,63 \mathrm{~km}^{2}$ or $38.04 \%$ of the PMA territory (see fig. 1). But the pressure of urbanisation and road network investment continues to grow. For example, many new housing estates have been built in recent years in the buffer zone of Wielkopolska National Park.

In recent years, environmental issues have become more prominent in local transport strategy. This is due mainly to Poland's accession to the European Union and its adoption of EU transport policy. Since 2006, when the first 'sustainable' transport strategy was accepted in the PMA, public transport as well as non-motorised forms of transport (cycling, walking) have been prioritised in local urban transport policy (tab. 2). There has been investment in tramlines and cycling paths. 


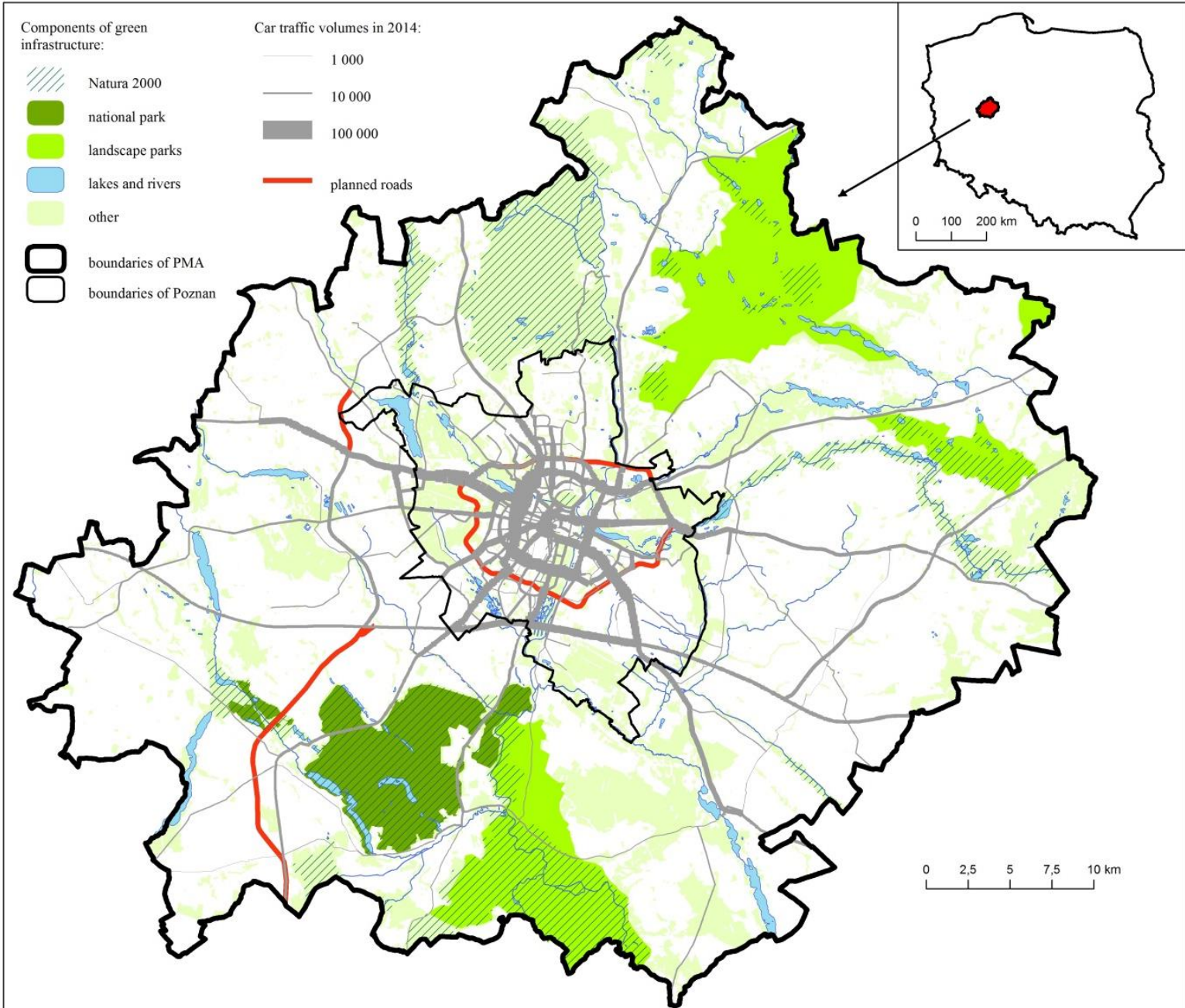

Figure 1: Road network and green infrastructure in Poznań Metropolitan Area (source: own compilation).

Table 2: Transport policy in Poznań Metropolitan Area after 2006

\begin{tabular}{|c|c|c|c|}
\hline Strategy & Documents & Main objectives & $\begin{array}{l}\text { Detailed } \\
\text { (selected) }\end{array}$ \\
\hline $\begin{array}{l}\text { Poznań } \\
\text { Transport } \\
\text { Policy } \\
2006 \text { - } 2013\end{array}$ & $\begin{array}{l}\text { Sustainable Plan for the } \\
\text { Development of Public } \\
\text { Transport for Poznan } \\
\text { Metropolitan Area, } \\
\text { Road Transport Policy, } \\
\text { Parking Policy, } \\
\text { Bicycle Transport Policy, } \\
\text { other local strategies and } \\
\text { urban plans }\end{array}$ & $\begin{array}{l}\text { [...] the achievement } \\
\text { of a sustainable } \\
\text { transportation } \\
\text { system in economic, } \\
\text { spatial, ecological } \\
\text { and social terms. }\end{array}$ & $\begin{array}{l}\text { - to increase the } \\
\text { percentage of public } \\
\text { transport in travel, } \\
\text { - to triple the } \\
\text { percentage of bicycle } \\
\text { traffic in urban } \\
\text { transportation, } \\
\text { - to eliminate heavy } \\
\text { vehicle traffic through } \\
\text { the city, } \\
\text { - to change travel } \\
\text { behaviour and reduce } \\
\text { car traffic. }\end{array}$ \\
\hline
\end{tabular}




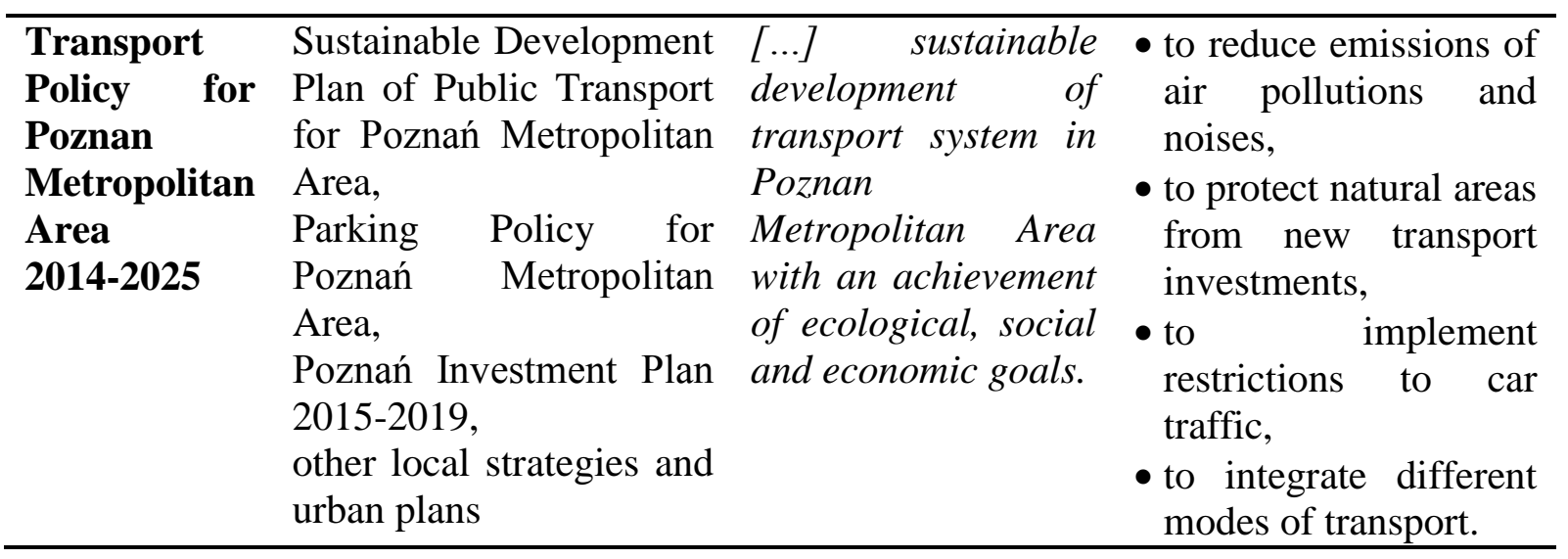

Although environmental issues became more important in PMA transport policy after after 2006, actual changes have often been in conflict with approved objectives (also under other strategies). Between 2004 and 2014, several projects for the construction, reconstruction or modernisation of road infrastructure were implemented, funded by the European Union (in Poznań alone 12 projects with a total value of PLN 1115 million were financed - see more in Gadziński 2014). In Poznan poviat new expressways (functioning as bypasses) were built, encouraging more residents to leave Poznan and start a new life in the suburbs. Most opt for private cars in daily transport, so that car usage is increasing (tab. 1). Furthermore, new roads often intersect green corridors and in the immediate future could significantly lower the quality of the whole green infrastructure network. In effect, almost none of the objectives detailed in the Poznan Transport Policy 2006-2013 (see tab. 2) that relate to environmental issues were attained. In the opinion of many specialists, the situation has even worsened. In a new document (Transport Policy for Poznan Metropolitan Area 2014-2025), very similar objectives have therefore been incorporated (tab. 2). But if the low level of attention and investment devoted to environmental issues by the authorities persist, the prospects are bleak.

\section{Assessment of negative impacts \\ Research method}

To assess the present and future impacts of roads on the green infrastructure I used kernel density estimation (KDE). This method allows the density of spatially diverse phenomenon to be assessed. According to Anderson (2009, p. 360), KDE involves "placing a symmetrical surface over each [observation] and then evaluating the distance [from the observation] to a reference location based on a mathematical function and then summing the value for all the surfaces for that reference location." Finally, individual kernels for all observations are summed and we obtained the density estimate for the distribution of the phenomena under study. With KDE it is possible to analyse sets of point and line objects with different rates. What is more, there is no need to choose the distribution type of phenomena. In this study I used KDE to estimate rates of potentially negative impacts.

$\mathrm{KDE}$ is occasionally used in transport and environmental studies. For example Xie and Yan (2008) and Anderson (2009) used it to estimate the risk of road accidents. Botte and Olaru $(2010,2012)$ calculated zones of economic activity around new transport investments. Among environmental studies where KDE were used is the study by Azomahou et al. (2001), who examine the relationship between GDP and $\mathrm{CO}_{2}$ emissions. Very interesting are also studies on green infrastructure fragmentation by Teng et al. (2011). Using KDE, they investigated Wuhan city, identifying multiple needs for priority greenway networks. They conclude that the "kernel density method is an effective tool to illustrate priorities by revealing the potential utilisation intensity of corridors" (Teng et. al., 2011, p. 1). Generally, it 
seems that KDE is a good tool to identify hot spots and to predict future scenarios (which are generally difficult to predict by parametric methods). On the other hand, I should also mention its weaknesses, such as subjectivity in the selection of parameters and in the interpretation of results (Botte and Olaru 2012).

The standard model for the kernel density function can be represented by the following formula (Silverman 1986; Xie and Yan 2008):

$$
\lambda(S)=\sum_{i=1}^{n} \frac{1}{\pi r^{2}} k\left(\frac{d_{i S}}{r}\right),
$$

where:

- $\lambda(S)$ is a density at point $S$,

- $n$ is a number of observations,

- $k\left(\frac{d_{i S}}{r}\right)$ is a kernel function ( $k$ is a weight of point $i$ in a distance $d_{i S}$ from point $S$ ),

- $r(>0)$ is a bandwidth - radius of a circle with a centre in point $S$, where points $S_{i}$

influence an intensity of $\lambda(S)$; it is determining a level of smoothing.

The kernel function could be of different types depending on the selection of an analytical function (see more in: Bowman, Azzalini 1997, De Smith et al., 2007). In all analyses in this study, I used Epanecznikov's kernel, which is the typical function used in ArcGIS software (this program was used to conduct all analyses). Interpretation of results obtained seems quite easy - greater values show higher densities and greater potential impact.

\section{Increase of road impacts 2006-2014}

To assess changes in the levels of negative impacts between 2006 and 2014, I measured (with KDE) the density of national and regional roads. In Poznan other categories of roads with high importance were also included in the study. Car traffic volumes on main roads were treated as Z-values (weights) in the model. They were obtained from the General Directorate of National Roads and Motorways (GDDKiA). This data is based on research at 5-year intervals $(2005,2010,2015)$, when GDDKiA collects the latest statistics on car traffic volumes (data for particular years - 2006 and 2014 - were calculated with the methodology proposed by GDDKiA). I also took into account the differences in the road network between 2006 and 2014 - since 2006 two new segments of expressway (S11 and S5) have notably been built in Poznan poviat. The bandwidth was established at two kilometres, which generally corresponds with the distance recognized in the literature as a range of road impacts (see Garcia-Montero et al., 2010). The statistical analysis was possible thanks to ArcGIS software (version 9.3). Good quality raster pictures allowed a very detailed assessment using previously gathered data (Polichtchouk, 1998). The area of the Poznań agglomeration was divided into 854,902 cells (pixels) of $50 \mathrm{~m} \times 50 \mathrm{~m}$ each. For each cell the value of kernel density was calculated (fig. 2). 

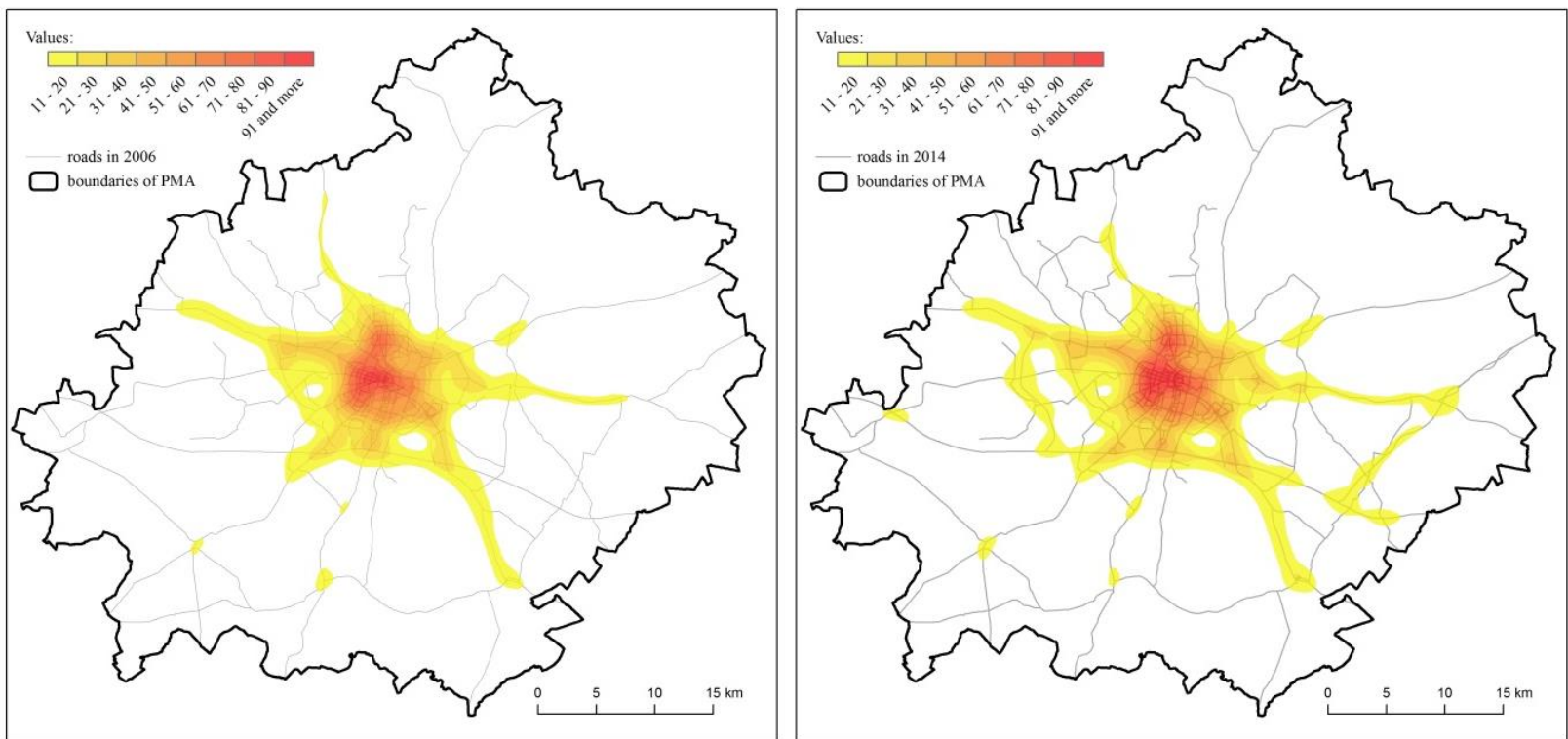

Figure 2: Negative impacts of road transport in 2006 and 2014 (source: own compilation).

Results for 2006 range from 0.00 (lowest values) to 93.86 (highest values). The median was 3.29 and the standard deviation 9.02. When I excluded zero values, which represented almost $58 \%$ of all observations, the median rose to 7.56 and the standard deviation to 12.54 . The results obtained for 2014 were generally higher and ranged from 0.00 to 103.25. The median was 4.01 and, with zero values excluded, it increased to 9.04. Respectively the standard deviation without zero values rose from 10.10 to 13.73 .

2006

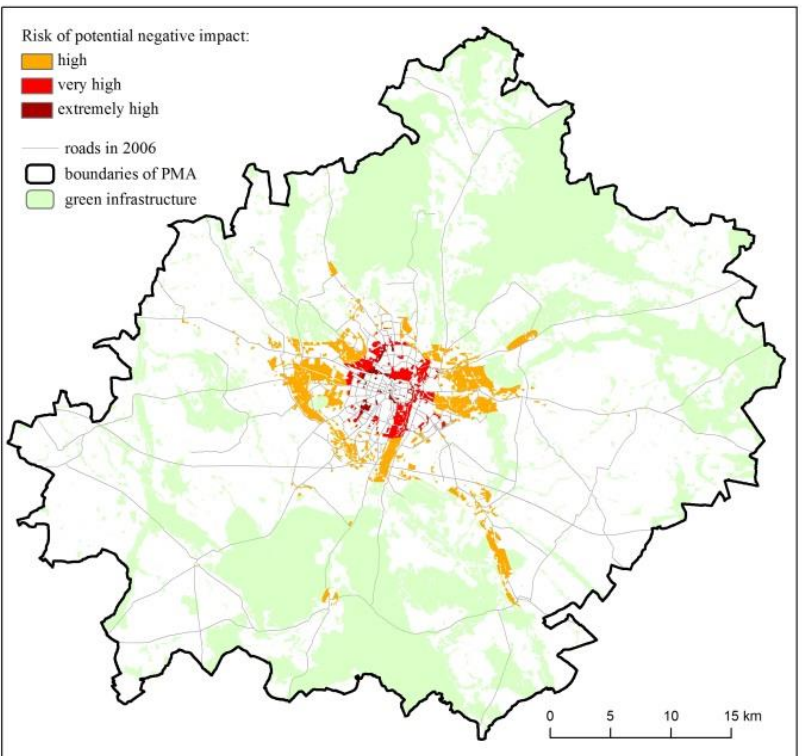

2014

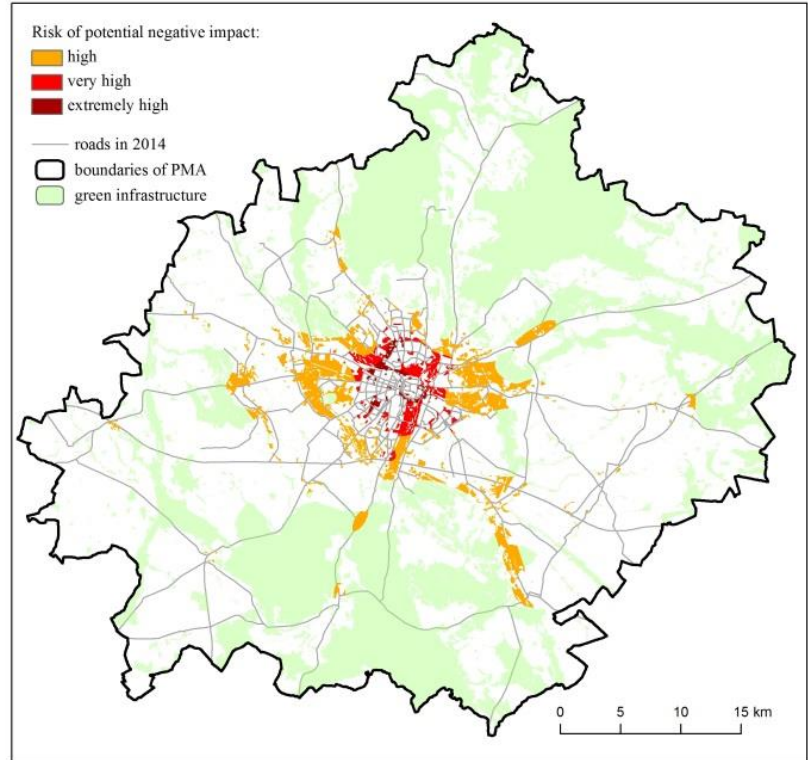

Figure 3: Hot spots in 2006 and 2014 (source: own compilation).

To interpret obtained results some subjective assumptions should be implemented. On a map (Fig. 3) I skipped values lower than 11 to facilitate perception. Cells with such values could be interpreted as areas with no (0.00) or little impact (values: 0.01-10.99). Cells with values between 11.00 and 93.86 I considered as areas with significant negative impact. Generally they are clustered in the central part of PMA and around the main roads connecting Poznan with surrounding communes. Some significant differences between 2006 and 2014 
are easily visible. Total area of cells with significant negative impact in 2006 was $243.91 \mathrm{~km}^{2}$. In 2014 it rose to $336.11 \mathrm{~km}^{2}$ and a total increase was $37,80 \%$.

In a second phase I compared the results obtained with the picture of green infrastructure in the PMA. This allowed me to indicate hot spots - areas where the pressure of the road network tend (potentially) to be the most important 'problem' for the green infrastructure. As green infrastructure I included large areas of natural vegetation (protected areas, forests, parks) and linear features (mainly river and stream corridors and post-glacial channels). I also included rivers and lakes in this category (sometimes recognized as 'blue infrastructure') most of them are located within protected areas or in valleys and channels surrounded by forests and meadows. As a result, analyses in the PMA green infrastructure covered 821, 63 $\mathrm{km}^{2}$.

I recognised hot spots as areas where both 'significant negative impacts' and 'green infrastructure' were present (fig. 3). In 2006 these conflict spots covered $67.19 \mathrm{~km}^{2}$ and in $2014-81.12 \mathrm{~km}^{2}$ (total increase 20,73\%). The percentage of green infrastructure that was potentially threatened increased from $8.18 \%$ in 2006 to $9.87 \%$ in 2014 . I also divided areas into three types differentiated by the risk of potential negative impact. Areas with a 'high risk' of such impact were cells with values from 1.00 to 3.99. Cells with values between 3.00 and 6.99 were classified as areas with a 'very high risk' and those with values over 6.99 - as areas with an 'extremely high risk'. In 2006 these three categories covered respectively $79.44 \%$ $\left(53.375 \mathrm{~km}^{2}\right), 17.73 \%\left(11.916 \mathrm{~km}^{2}\right)$ and $2.83 \%\left(1.90 \mathrm{~km}^{2}\right)$ of all threatened areas. By 2014 this relation had slightly changed. Areas with a 'high risk' of impact in 2014 covered $80.21 \%$ $\left(65.07 \mathrm{~km}^{2}\right)$, with a 'very high risk' $15.13 \%\left(12.27 \mathrm{~km}^{2}\right)$ and with an 'extremely high risk' $4.65 \%\left(3.77 \mathrm{~km}^{2}\right)$.

\section{Perspectives for the future}

To predict the possible situation in 2025 I proposed four scenarios. They differ in terms of the level of future traffic increase and the possibility of new investment in the infrastructure. I omit other variables such as possible technological improvements (reducing emissions), new legal regulations, or possible rapid changes in people's travel behaviour because of their very low predictability. The first scenario presents the situation in which no changes occur until 2025, and in the last scenario both the motorisation level and network density rise. In the second and third scenarios, only one variable changes. All scenarios are presented in table 3. They should be considered rather as extreme situations; actual future road impacts would probably be a mix of them.

Table 3: Proposed scenarios of future roads impact.

\begin{tabular}{lll}
\hline & Car traffic volumes on roads & Network development \\
\hline Scenario 1 & stable & no new infrastructure investment \\
Scenario 2 & increase & no new infrastructure investment \\
Scenario 3 & stable & realisation of planned investment \\
Scenario 4 & increase & realisation of planned investment \\
\hline
\end{tabular}

Motorisation growth until 2025 was assessed on the basis of variables proposed by GDDKiA which correlates strongly to an increase in the GDP of the country. These calculations predict a stable increase in car traffic volumes on the roads in the Poznan agglomeration. Of course, this seems to be a simplification. According to the literature, the level of motorisation does not always correlate with an increase in GDP (see Dargay and Gately, 1999). In many cases other factors appear to be more important (for example the level of motorisation could be influenced by urban sprawl, changes in lifestyle, improvements in the accessibility of public transport, and so on). As many examples from Western countries 
have shown (see Cairns et al. 2002), it is therefore obvious that the level of motorisation may not still be growing and that there are certain limits. Despite these limitations, I adopted this factor as the extreme situation and maximum possible growth of traffic flows. In the PMA, the total increase of traffic volumes predicted for the period 2014-2025 was 37.82\%.

Road network development was chosen as a second factor that could influence the level of negative impacts on the green infrastructure. It was assessed on the basis of national and local government planning. I took into account only the main road investments envisaged by the Transport Development Strategy (2012) and local transport strategies. Obviously, not all planned infrastructure can be built by the end of 2025. It depends on the local budget situation, current policy priorities, the accessibility of national and international grants (for example from EU funds), etc. In this context, road construction set out in local and national plans can be considered as the maximum possible development of the network. In the PMA between 2014 and 2025, a 5.26\% growth is predicted in the length of the roads under study.

For all scenarios I conducted similar analyses as for 2006 and 2014 (in part 4.2) using KDE. The results are presented in maps (Fig. 4 and 5) and in table 4.

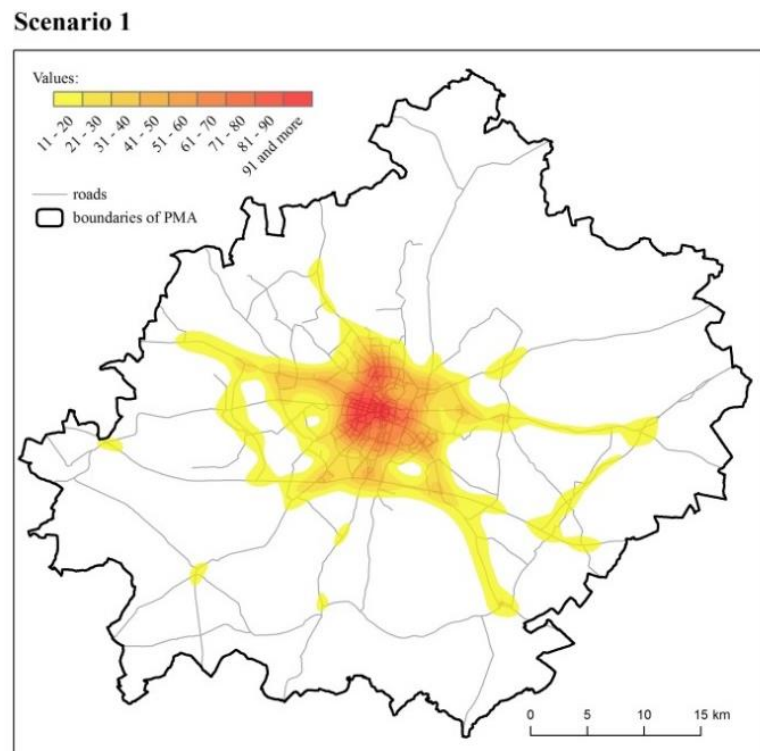

Scenario 2

Scenario 3
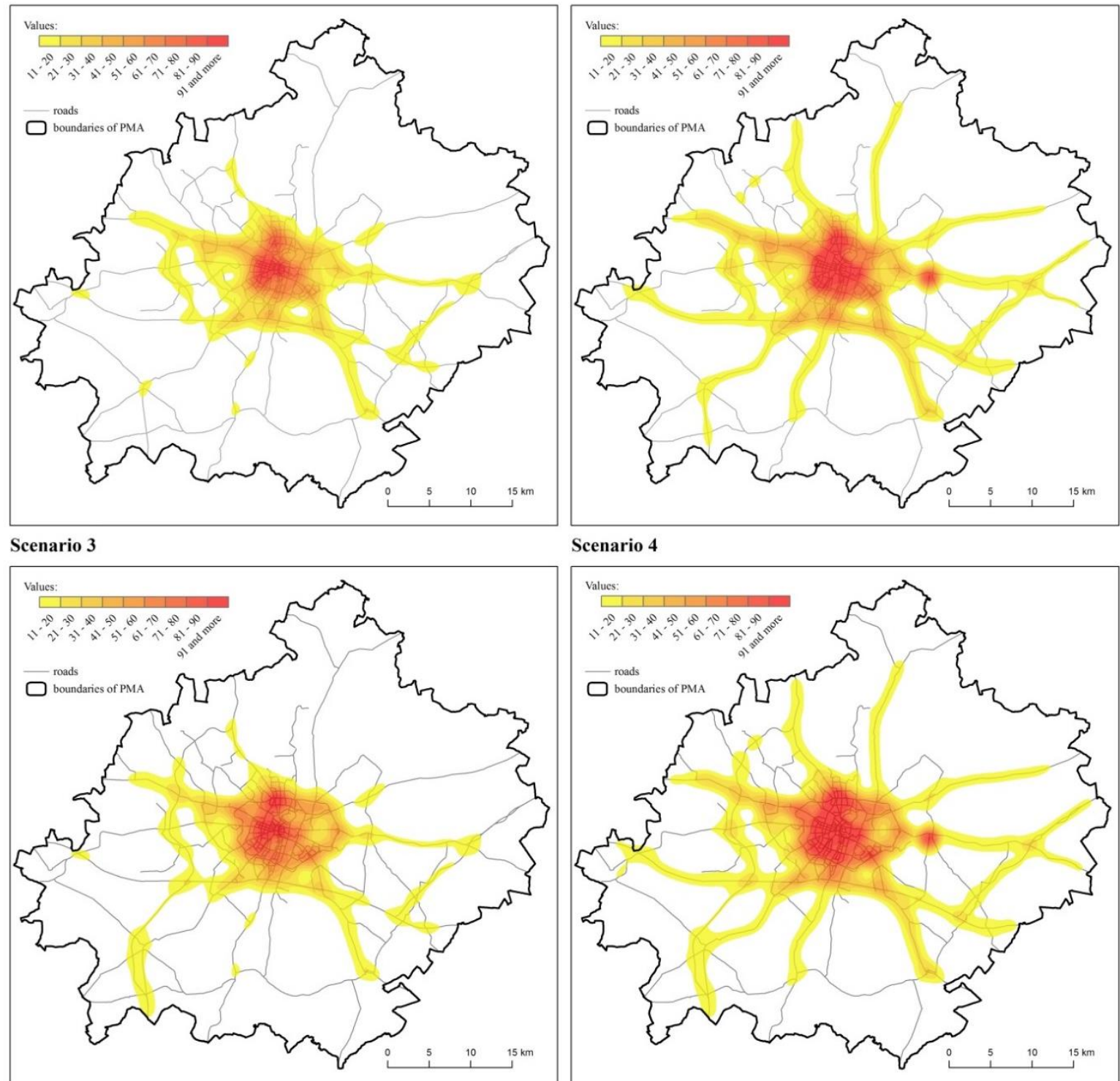

Scenario 4

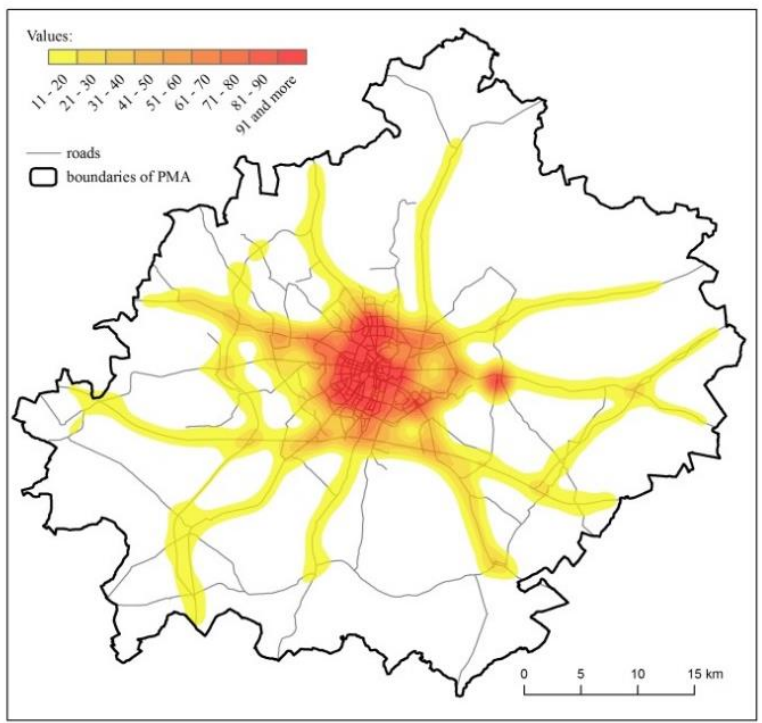

Figure 4: Possible negative impacts of road transport in 2025 (source: own compilation). 
Table 4: Results of KDE for 4 future scenarios.

\begin{tabular}{|c|c|c|c|c|c|c|}
\hline \multirow[b]{3}{*}{ Scenario 1} & \multirow[t]{2}{*}{$\begin{array}{l}\text { Median } \\
\text { values }\end{array}$} & \multirow{2}{*}{$\begin{array}{l}\begin{array}{l}\text { Average index } \\
\text { change } \\
(2014=1)\end{array}\end{array}$} & \multicolumn{4}{|c|}{$\begin{array}{l}\text { Areas with a risk of potential negative impact on } \\
\text { green infrastructure }\left(\text { in } \mathbf{k m}^{2}\right) \text { : }\end{array}$} \\
\hline & & & total & high & very high & extremely high \\
\hline & 3,98 & 1 & 81,11 & 65,07 & 12,27 & 3,77 \\
\hline Scenario 2 & 5,74 & 1,44 & 133,26 & 107,25 & 15,80 & 10,21 \\
\hline Scenario 3 & 4,60 & 1,16 & 88,64 & 60,44 & 22,16 & 6,04 \\
\hline Scenario 4 & 6,32 & 1,60 & 137,79 & 101,30 & 22,02 & 14,47 \\
\hline
\end{tabular}

Unsurprisingly, the range of negative road impacts in scenarios 2-4 had significantly increased since 2014 (as with the situation in 'scenario 1'). In 'scenario 2' when only an increase in car traffic flows was predicted, results ranged from 0.00 to 140.80 . The median was 5.74 and the standard deviation 15.12 (with zero values excluded respectively 12,89 and 19,04). In 'scenario 3' when car traffic flows were stable but new road infrastructure was constructed, values were lower (between 0.00 and 103.69). The median was 5.60 and the standard deviation 11.75. But when zero values were excluded, the median increased to 10.27 and the standard deviation to 19.57. In the last scenario (both increasing traffic flows and new transport investments) the same range of values as in 'scenario 2' was obtained (0.00-140.80). The median and standard deviation reached the highest levels in the analysis - respectively 6.32 and 15.58. And without zero values the results were 14.04 for the median and 20.94 for the standard deviation. The total change in results between scenario 1 and 4 was $60 \% .44 \%$ of this increase in negative impact was an effect of predicted car traffic flows (situation in 'scenario 2') and 16\% resulted from new transport investments (situation in 'scenario 3').

When comparing the results with the picture of green infrastructure in the PMA (fig. 5), I found a significant increase in the range of areas threatened by road impacts (table 4). In 'scenario 4' these impacts cover almost all elements of the green infrastructure around main roads in the PMA. What is more, almost all green spaces in the city of Poznan were exposed to degradation and the risk of negative impacts was 'very high' or 'extremely high' there. The area of hot spots was the slightly smaller in 'scenario 2' (only $4 \mathrm{~km}^{2}$ less) and significantly smaller in 'scenario 3' (almost $50 \mathrm{~km}^{2}$ less). This is because not very long sections of new roads are planned up to 2025, especially in Poznan poviat, so the effects would be limited only to small parts of the green infrastructure network (situation in 'scenario 3').

What is also interesting about the results is that the share of areas with 'very high' and 'extremely high' risk of road impacts was highest in scenario 3 (almost $31.81 \%$; in 'scenario 2 ' $19.52 \%$ and in 'scenario 4' $26.48 \%$ ). This is because of the ring road planned within the boundaries of the city of Poznań. The impact of a dense road network is already a serious risk for the green infrastructure in the area, and new roads with high volumes of car traffic will bring an increase in potential threats. What is more, the new bypass will have to intersect many green spaces including many linear forms of green infrastructure (for example green corridors along the Warta river). There is therefore a risk of significant fragmentation and lower ecological security throughout the network (compare Teng et al., 2011). 


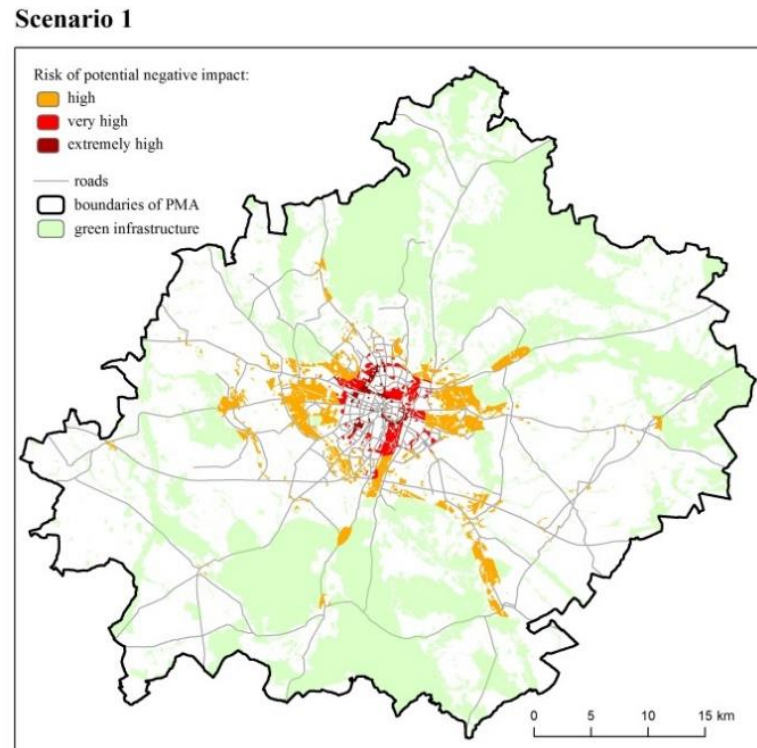

Scenario 2
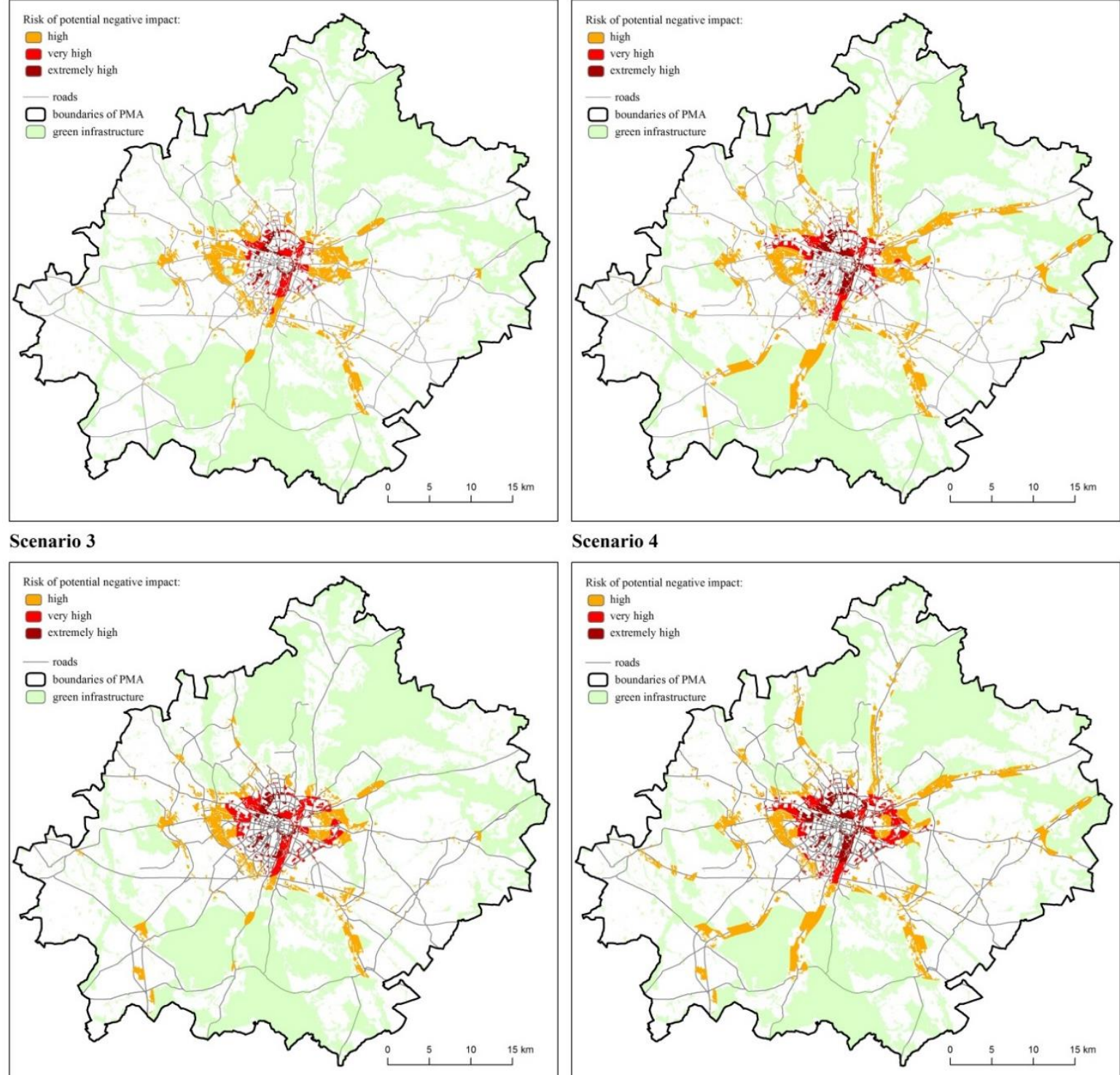

Scenario 4

Figure 5: Possible range of hot spots in 2025 (source: own compilation).

\section{Conclusions}

These analyses clearly show that motorisation is exerting growing pressure on the green infrastructure in the PMA. This confirms the hypothesis that in the PMA a reduction of transport impacts on the natural environment (postulated in transport strategies since 2006) has not been implemented in reality. Analyses show that between 2006 and 2014 the scale of negative impacts has grown significantly. This could have a negative impact not only on natural environment by also on residents' health and standard of living. KDE results show that areas potentially threatened by roads and traffic covered more than $80 \mathrm{~km}^{2}$ - mainly central parts of Poznań with the highest population density and limited green spaces. The reason for increasing impacts can be found in the recent pattern of action by national and local authorities. In Poznan (as well as in other large Polish urban centres) in recent years, the most popular and expensive investments have included new road connections to ensure high capacity and fast links between the centre and the outskirts. In the PMA in effect suburbanisation is an increasing problem and a cause of urban sprawl. As Plane (1986) has suggested, this leads nowhere because improved road facilities make travel easier, which stimulates the increase in average trip length and in the number of trips being made. 
Migrations produce a need for even more facilities and the feedback process repeats itself. Among the negative consequences of this situation are the growing number and use of vehicles and congestion (Newman, Kenworthy, 1999). As a result, the pressure on the green infrastructure continues to grow. And as research has shown, many new areas have come under threat in the vicinity of new transport infrastructures.

Nevertheless, one of the most eagerly awaited projects is the construction of city ring roads, which will separate several green infrastructure corridors and could cause significant deterioration in the quality of the natural environment. The volumes of traffic flows predicted are also very alarming. According to GDDKiA calculations, they could increase by $37.82 \%$ by 2025 . In effect, perspectives for the future are not very favourable. In all our scenarios (except 'scenario 1' with no changes) there was a clear increase in the range of hot spots. In the worst case ('scenario 4') they would grow in area by $60 \%$. If trends in travel behaviour do not change, green infrastructure quality and continuity will therefore be threatened and their ecological security level may fall.

The findings of recent studies on resident travel behaviour in the PMA are also rather alarming. Investigations conducted in 2012 showed that cars are the most desirable mode of transport (see Gadziński, 2013). In this study almost $51 \%$ of respondents declared that in the immediate future they intended to use cars in daily trips in the city, while only $18 \%$ opted for public transport. For historical reasons and particularly because of the limited availability of cars before system transition (see Pucher, 1995), the car is still an important material status symbol and a measure of success for some social groups. Public transport, by contrast, is often associated with children, students, pensioners, and low-income groups (Beirão and Cabral, 2007; Steg, 2005), although some progressive changes in mentality have occurred.

The survey mentioned (Gadziński, 2013) also invited respondents to react to specific proposals for solving transport problems and increasing traffic flows, which usually seek to introduce certain restrictions on motor traffic. The idea of calming traffic in central parts of the city gained the largest number of supporters $(42 \%)$, although there were nearly as many opponents to this solution (41\%). For other solutions, the majority of residents proved to be opponents of change. The expansion of paid parking zones was especially strongly protested (65\% of the residents). The results show that not everyone can understand the need for change to create a more sustainable transport system in which modes of transport other than cars that are more effective in the urban space are preferred. It is therefore necessary to educate people in this respect and to learn from patterns and solutions (so called good practices) to be found in other cities. The survey results also show that it is not always easy to determine the direction of transport policy.

To sum up, for the future a never-ending programme of road building is not the answer (Chapman 2007). Once the backlog in infrastructural development has been at least partially eliminated, major Polish cities should proceed to implement other aspects of transport sector strategy. It is therefore important to focus on the investments that improve existing network quality - modern traffic management systems, solutions to integrate different modes of transport and facilitate transfers (or the transhipment of goods), as well as the accessibility of public transport (Van Wee 2002, Gaffron et al. 2007). These improvements would also help reduce and neutralise major negative road impacts.

In the immediate future, cities will need to make more radical changes to reduce the role of road transport and to make greater efforts in land conservation and establishing complex networks of green infrastructure. Future investment should focus on the solutions that are positive from the general social point of view, and not those that improve living conditions for only a small section of the population (Banister et al., 2000, Whitelegg 2003). The most important tasks include appropriate policy planning that would to at least some extent reduce the need for mobility (e.g. by reducing further settlement dispersion). At the same time, 
ecological issues should be emphasized not only in transport strategies but also in the action taken on the ground by authorities.

\section{References}

Anderson, T. K. (2009) Kernel density estimation and K-means clustering to profile road accident hotspots. Accident Analysis \& Prevention, 41(3), pp. 359-364. DOI: 10.1016/j.aap.2008.12.014

Angold, P. G. (1997) The impact of a road upon adjacent heathland vegetation: effects on plant species composition. Journal of Applied Ecology, pp. 409-417. DOI: $10.2307 / 2404886$

Azomahou, T., Van Phu, N., \& Laisney, F. (2001) Economic growth and $\mathrm{CO}_{2}$ emissions: a nonparametric approach. BETA Working Paper 2001-01, Université Louis Pasteur, Strasbourg.

Banister D. (2011) Cities, mobility and climate change. Journal of Transport Geography, 19, pp. 1538-1546. DOI: 10.1016/j.jtrangeo.2011.03.009

Banister, D. Stead D., Steen P., Akerman J., Dreborg K., Nijkamp P. \& Tappeser R.S. (2000) European transport policy and sustainable mobility. Routledge, London.

Beirão, G. \& Cabral, J.A.S. (2007) Understanding attitudes towards public transport and private car: A qualitative study. Transport policy 14(6), pp. 478-489. DOI: 10.1016/j.tranpol.2007.04.009

Benedict, M.A., \& McMahon, E.T. (2006) Green infrastructure: Smart Conservation for the 21st Century. Sprawl Watch Clearinghouse, Washington.

Bennett, A. F. (1991) Roads, roadsides and wildlife conservation: a review. In: Saunders DA \& Hobbs RJ. (eds.) Nature Conservation 2: The Role of Corridors, pp. 99-118. Chipping Norton, Surrey Beatty.

Botte M. \& Olaru D. (2010) Exploring activity space metrics along a new transit oriented development railway corridor. In: M. De Smith, M. Goodchild \& P. Longley. (eds.) Geospatial analysis: a comprehensive guide to principles, techniques and software tools, pp. 978-989. Leicester, Troubador Publishing Ltd.

Botte M. \& Olaru D. (2012) Geo-spatial analysis of activity spaces in a TOD environment - tracking impacts of rail transport policy using kernel density estimation. Road \& Transport Research Journal, 21(1), pp. 64-81.

Bowman A.W. \& Azzalini A. (1997) Applied smoothing technics for data analysis. Oxford Univ. Press, Oxford.

Button, K., \& Nijkamp, P. (1997) Social change and sustainable transport. Journal of Transport Geography, 5(3), pp. 215-218. DOI: 10.1016/S0966-6923(97)00018-5

Cairns, S., Atkins, S., \& Goodwin, P. (2002) Disappearing traffic? The story so far. Proceedings of the ICE-Municipal Engineer, 151(1), pp. 13-22. DOI: 10.1680/muen.2002.151.1.13

Chapman, L. (2007) Transport and climate change: a review. Journal of transport geography, 15(5), pp. 354-367. DOI: 10.1016/j.jtrangeo.2006.11.008

Coffin, A. W. (2007) From roadkill to road ecology: a review of the ecological effects of roads. Journal of transport Geography, 15(5), pp. 396-406. DOI:

10.1016/j.jtrangeo.2006.11.006

Dargay, J., \& Gately, D. (1999) Income's effect on car and vehicle ownership, worldwide: 1960-2015. Transportation Research Part A: Policy and Practice, 33(2), pp. 101-138. DOI: 10.1016/S0965-8564(98)00026-3

De Smith P., Martino D., Cai Z., Gwary D., Janzen H.H., Kumar P., et al. (2007) Policy and technological constraints to implementation of greenhouse gas mitigation options 
in agriculture. Agriculture, Ecosystems and Environment, 118, pp. 6-28. DOI: 10.1016/j.agee.2006.06.006

Develey, P. F., \& Stouffer, P. C. (2001) Effects of Roads on Movements by Understory Birds in Mixed-Species Flocks in Central Amazonian Brazil. Conservation Biology, 15(5), pp. 1416-1422. DOI: 10.1111/j.1523-1739.2001.00170.x

The European Commission (2001) European transport policy for 2010: time to decide. Brussels, The European Commission.

Forman, R. T. (1998) Road ecology: a solution for the giant embracing us. Landscape Ecology, 13(4), pp. III-V. DOI: 10.1023/A:1008036602639

Forman R.T., Sperling D., Bissonette J., Clevenger A.P., Cutshall C., Dale V. et al. (2003) Road Ecology: Science and Solutions. Washington, Island Press.

Forman, R. T., \& Alexander, L. E. (1998). Roads and their major ecological effects. Annual review of ecology and systematics, pp. 207-C2. DOI: 10.1146/annurev.ecolsys.29.1.207

Gadziński J. (2013) Funkcjonowanie lokalnego system transportowego na tle współczesnych procesów urbanizacyjnych. Przykład aglomeracji poznańskiej. (Functioning of the local transport system against the background of contemporary processes of urbanization. Example of Poznań agglomeration). Poznań, Bogucki Wydawnictwo Naukowe.

Gadziński J. (2014) The impact of EU policies on the modernization of transport infrastructure in Poznań and other major Polish cities. In: P. Churski \& $T$. Stryjakiewicz (eds.), Poznań - an attempt to assess changes during 10 years of membership in the European Union, pp. 79-90. Poznań, Bogucki Wydawnictwo Naukowe.

Gaffron, P., Schubert Uwe, Skala, F. \& Wagner, T. (2007) Planning urban structures for sustainable transport. In: S. Marshall \& D. Banister (eds.), Land use and transport, pp. 71-103. Oxford, Elsevier.

Gaj H. (2008) Bilans cieplarniany gazów dla miasta Poznania. Poznań, Agpress.

Gayda S. \& Lautso K. (2007) Urban sprawl and transport. In: Marshall, S. \& Banister, D. (eds.), Land use and transport, pp. 177-216. Oxford, Elsevier.

García-Montero, L. G., López, E., Monzón, A., \& Pastor, I. O. (2010) Environmental screening tools for assessment of infrastructure plans based on biodiversity preservation and global warming (PEIT, Spain). Environmental Impact Assessment Review, 30(3), pp. 158-168. DOI: 10.1016/j.eiar.2009.08.008

Geneletti, D. (2003) Biodiversity impact assessment of roads: an approach based on ecosystem rarity. Environmental impact assessment review, 23(3), pp. 343-365. DOI: 10.1016/S0195-9255(02)00099-9

Glasson, J., Therivel, R., \& Chadwick, A. (2013) Introduction to environmental impact assessment. London, Routledge.

Harris, L. D., \& Scheck, J. (1991) From implications to applications: the dispersal corridor principle applied to the conservation of biological diversity. Nature conservation, 2, pp. 189-220.

Hawbaker, T. J., Radeloff, V. C., Clayton, M. K., Hammer, R. B., \& Gonzalez-Abraham, C. E. (2006) Road development, housing growth, and landscape fragmentation in northern Wisconsin: 1937-1999. Ecological Applications, 16(3), pp. 1222-1237. DOI: 10.1890/1051-0761(2006)016

Hellawell, J. M. (1988) Toxic substances in rivers and streams. Environmental Pollution, 50(1), pp. 61-85. DOI: 10.1016/0269-7491(88)90185-6 
Holden, E., \& Høyer, K. G. (2005) The ecological footprints of fuels. Transportation Research Part D: Transport and Environment, 10(5), pp.395-403. DOI: 10.1016/j.trd.2005.04.013

João, E. (2002) How scale affects environmental impact assessment. Environmental impact assessment review, 22(4), pp. 289-310. DOI: 10.1016/S0195-9255(02)00016-1

Johnson, M. P. (2001) Environmental impacts of urban sprawl: a survey of the literature and proposed research agenda. Environment and Planning A, 33(4), pp. 717-735. DOI: $10.1068 / \mathrm{a} 3327$

Kenworthy, J. R. (2006) The eco-city: ten key transport and planning dimensions for sustainable city development. Environment and urbanization, 18(1), pp. 67-85. DOI: $10.1177 / 0956247806063947$

Li, X., Wang, W., Li, F., \& Deng, X. (1999) GIS based map overlay method for comprehensive assessment of road environmental impact. Transportation Research Part D: Transport and Environment, 4(3), pp. 147-158. DOI: 10.1016/S13619209(99)00002-4

Macias, A., \& Gadzinski, J. (2013) Assessment of road transport environmental impact as illustrated by a metropolitan area. Polish Journal of Environmental Studies, 22(6), p. 1749.

McDonald, L., Allen, W., Benedict, M., \& O'connor, K. (2005) Green infrastructure plan evaluation frameworks. Journal of Conservation Planning, 1(1), pp. 12-43.

Mess P. (2010) Transport for suburbi:. Beyond the automobile age. London, Earthscan.

Nellemann, C., Vistnes, I., Jordhøy, P., \& Strand, O. (2001) Winter distribution of wild reindeer in relation to power lines, roads and resorts. Biological Conservation, 101(3), pp. 351-360. DOI: 10.1016/S0006-3207(01)00082-9

Newman, P. (2006) The environmental impact of cities. Environment and Urbanization, 18(2), pp. 275-295. DOI: 10.1177/0956247806069599

Newman P., Kenworthy J. (1999) Cities and Sustainability: Overcoming automobile dependence. Washington, Island Press.

Pant, P., \& Harrison, R. M. (2013) Estimation of the contribution of road traffic emissions to particulate matter concentrations from field measurements: a review. Atmospheric Environment, 77, pp. 78-97. DOI: 10.1016/j.atmosenv.2013.04.028

Polichtchouk Y (1998) Geoinformation systems and regional environmental prediction. Safety Science, 30, pp. 63-70. DOI: 10.1016/S0925-7535(98)00033-2

Polkowska, Ż., Grynkiewicz, M., Zabiegała, B., \& Namieśnik, J. (2001) Levels of pollutants in runoff water from roads with high traffic intensity in the city of Gdańsk, Poland. Polish Journal of Environmental Studies, 10(5), pp. 351-363.

Pucher, J. (1995) The road to ruin? Impacts of economic shock therapy on urban transport in Poland. Transport Policy 2(1), pp. 5-13. DOI: 10.1016/0967070X(95)93241-P

Roadmap to a Single European Transport Area - towards a competitive and resource efficient transport system (2011) The European Commission. Brussels.

Rogge, W. F., Hildemann, L. M., Mazurek, M. A., Cass, G. R., \& Simoneit, B. R. (1993) Sources of fine organic aerosol. 3. Road dust, tire debris, and organometallic brake lining dust: roads as sources and sinks. Environmental Science \& Technology, 27(9), pp. 1892-1904. DOI: 10.1021/es00046a019

Saunders, S. C., Mislivets, M. R., Chen, J., \& Cleland, D. T. (2002) Effects of roads on landscape structure within nested ecological units of the Northern Great Lakes Region, USA. Biological conservation, 103 (2), pp. 209-225. DOI: 10.1016/S00063207(01)00130-6 
Schonewald-Cox, C., \& Buechner, M. (1992) Park protection and public roads. In: Fiedler P.L. \& Jain S.K. (eds.) Conservation biology, pp. 373-395. USA, Springer.

Silverman B.W. (1986) Density estimation for statistics and data analysis. Vol. 26 of Monographs on Statistics and Applied Probability. London, Chapman and Hall.

Smith, L.L., Smith, K.G., Barichivich, W.J., Dodd Jr., C.K., Sorensen, K. (2005) Roads and Florida's herpetofauna: a review and mitigation case study. In: Meshaka, W.E., Jr. $\&$ Babbitt, K.J. (eds.) Status and Conservation of Florida Amphibians and Reptiles. Florida (Malabar), Krieger Publications.

Spellerberg, I. A. N. (1998) Ecological effects of roads and traffic: a literature review. Global Ecology and Biogeography, 7(5), pp. 317-333. DOI: 0.1046/j.1466822x.1998.00308.x

Steg, L. (2005) Car use: lust and must. Instrumental, symbolic and affective motives for car use. Transportation Research Part A, 39(2), pp. 147-162. DOI: 10.1016/j.tra.2004.07.001

Teng, M., Wu, C., Zhou, Z., Lord, E., \& Zheng, Z. (2011) Multipurpose greenway planning for changing cities: A framework integrating priorities and a least-cost path model. Landscape and urban planning, 103(1), pp. 1-14. DOI: 10.1016/j.landurbplan.2011.05.007

Van Wee B. (2002) Land use and transport: research and policy challenges. Journal of Transport Geography, 10, pp. 259-271. DOI: 10.1016/S0966-6923(02)00041-8

Whitelegg J. (1994) Transport and land take. A report for CPRE. Lancaster, Eco-Logica Ltd.

Whitelegg, J. (2003) Transport in the European Union: time to decide. In: Low N. \& Gleeson B. (eds.) Making urban transport sustainable, pp. 115-131. Hampshire, Palgrave Macmillan UK.

Wickham, J. D., Riitters, K. H., Wade, T. G., \& Vogt, P. (2010) A national assessment of green infrastructure and change for the conterminous United States using morphological image processing. Landscape and Urban Planning, 94(3), pp. 186-195. DOI: 10.1016/j.landurbplan.2009.10.003

Xie Z. \& Yan J. (2008) Kernel Density Estimation of traffic accidents in a network space. Computers, Environment and Urban Systems, 32(5), pp. 396-406. DOI: 10.1016/j.compenvurbsys.2008.05.001

Yu K. (1996) Security patterns and surface model in landscape ecological planning. Landscape Urban Plan, 36(1), pp. 1-17. DOI: 10.1016/S0169-2046(96)00331-3 